\title{
Ichthyobodo spp. Infection in Meagre (Argyrosomus regius) from Turkey: Parasitological and Pathological Findings
}

\author{
Granyöz Balığıında (Argyrosomus regius) Ichthyobodo spp. Enfeksiyonunun Türkiye’den \\ Bildirimi: Parazitolojik ve Patolojik Bulgular
}

\author{
Banu Yardımcı', Gökmen Zafer Pekmezci', Behire Işı Didinen², Seçil Metin² \\ 'Ondokuz Mayıs Üniversitesi, Veteriner Fakültesi, Su Ürünleri Hastalıkları Anabilim Dalı, Samsun, Türkiye \\ ²üleyman Demirel Üniversitesi, Eğirdir Su Ürünleri Fakültesi, Isparta, Türkiye
}

\section{ABSTRACT}

Objective: The aim of this study is to describe the first report of Ichthyobodo spp. infection in meagre (Argyrosomus regius) fry in a marine aquaculture facility in Turkey.

Methods: The material of the study was composed of 30 meagre A. regius in 2-3 g weight taken from the fry adaptation unit of a fish farm in the Aegean Sea. In this study, parasitological and pathological examinations were performed on the meagre. Ichthyobodo spp. was determined on the body surfaces and gills.

Results: Pathological examination revealed grayish mucous and erosions between the pin head and lentin over the skin of the examined specimens. Microscopic examinations revealed significant spongiosis, vacuolar degeneration, and hyperplasia in epidermal malpighian cells and hyperplasia in goblet cells.

Conclusion: In the present study, Ichthyobodo spp. infection was for the first time determined in an alternative cultured meagre in Turkey. (Turkiye Parazitol Derg 2016; 40: 48-50).

Keywords: Ichthyobodo spp., Argyrosomus regius, histopathology, Turkey

Received: 03.11.2015

Accepted: 29.12 .2015

\section{ÖZ}

Amaç: Çalışmanın amacı Türkiye'de denizde yetiştiriciliği yapılan Granyöz balığı yavrularında Ichthyobodo spp. enfeksiyonunun ilk defa tanımlanmasıdır.

Yöntemler: Çalışmanın materyalini Ege denizindeki balık çiftliğinin yavru adaptasyon ünitesinden alınan 2-3 gr ağırlığındaki 30 balık oluşturdu. Patolojik ve parazitolojik inceleme yapıldı. Vücut yüzeyi ve solungaçlarda Ichthyobodo spp. tespit edilmiştir.

Bulgular: Patolojik incelemede, balıkların dış yüzeylerinin grimsi renkte bir mukus tabakası ile kaplı olduğu ve deri üzerinde toplu iğne başından mercimek büyüklüğüne değişen boyutlarda erozyonlar gözlendi. Mikroskobik incelemede, epidermiste malpighian hücrelerinde belirgin spongiosis, vakuoler dejenerasyon ve hiperplaziye ile birlikte goblet hücrelerinde de hiperplaziye rastlandı.

Sonuç: Sonuç olarak, yetiştiricilikte alternatif bir tür olan granyöz balıklarında Türkiye'de ilk defa Ichthyobodo spp. enfeksiyonu tanımlandı. (Turkiye Parazitol Derg 2016; 40: 48-50).

Anahtar Kelimeler: Argyrosomus regius, histopatoloji, Ichthyobodo spp., Türkiye

Geliş Tarihi: 03.11.2015

Kabul Tarihi: 29.12.2015

\section{INTRODUCTION}

Meagre Argyrosomus regius (Asso, 1801) is a teleost fish species that belongs to the Sciaenidae family. Meagre could be a suitable candidate species for the diversification of aquaculture in the Mediterranean region, and has been ranked in eighth position out of 27 species. The farming of meagre started in Europe in the second half of the 1990s in Italy and France, followed by Spain (2004), Turkey (2005), and Greece (2007), and has now also started in Egypt. Total aquaculture production of meagre has increased from a few tonnes in 2000 to approximately 4000 tonnes in 2008 and 10 000 tonnes in 2010 (1). Meagre has grown rapidly, with production output in 2011 exceeding over 14000 tonnes (2).

Address for Correspondence / Yazışma Adresi: Dr. Banu Yardımcı E.mail: byardimci@omu.edu.tr DOI: 10.5152/tpd.2016.4577

(C) Copyright 2016 Turkish Society for Parasitology - Available online at www.tparazitolderg.org

CTelif hakkı 2016 Türkiye Parazitoloji Derneği - Makale metnine www.tparazitolderg.org web sayfasından ulaşılabilir. 
The ectoparasitic flagellate Ichthyobodo spp. is known to induce ichthyobodosis in both wild and farmed fish populations. Ichthyobodosis causes heavy infections on the skin and gills and can cause mortality, representing a common problem in fish farms. Formerly known as Costia necatrix, it is an important cosmopolitan distribution issue. Ichthyobodo spp. (mostly recorded as I. necator) has been identified and reported with different freshwater and marine fish worldwide (3). Their life cycle includes one free-swimming dispersive phase, alternating with an attached, feeding stage. The flagellate has been frequently associated with outbreaks in cultured and aquarium fish (4). Until recently, the genus Ichthyobodo contained a single variable species, I. necator, identified from different hosts. However, small subunit ribosomal RNA gene sequences of parasites from different fish and environments have shown that I. necator actually represents several different species (5). An infected fish body surface may appear gray in color, with spots, discoloration, and mucus secretion. The action of the Ichthyobodo results in the destruction of epidermal cells, producing widespread pathological changes. Skin histopathological lesions include spongiosis, vacuolation, and edema, followed by degeneration and sloughing of epidermis (6).

The aim of this study was to describe the first report of Ichthyobodo spp. infection in meagre (A. regius) fry in a marine aquaculture facility in Turkey.

\section{METHODS}

A total of 30 meagre fish in an adaptation unit from a fish farm were randomly collected and transported to the laboratory for parasitological examination in August 2013. The investigation was performed with smear or squash preparations under a light microscope (magnification 100-1000×). Skin was scraped onto the slides, dried at room temperature, and stained with $5 \%$ Giemsa solutions. The flagellates were studied by light microscopy and identified as Ichthyobodo spp. by their morphological characteristics, which have been described by Lom and Dykova, 1992. Following the parasitological examination, the gills and skin were fixed in $10 \%$ neutral formaldehyde solution for pathological examination. Tissue samples were routinely processed and embedded in paraffin. Tissue sections 4-6 $\mu$ in width were stained with hematoxylin-eosin (HE) and examined under a light microscope.

\section{RESULTS}

All the fish samples were infected with Ichthyobodo spp. Specimens of free-swimming forms of Ichthyobodo spp. were identified by their oval body, which contained two free unequal flagellae ventrally and a centrally located nucleus (Figure 1a). Macroscopic examination revealed grayish mucous and erosions between the pin head and lentin over the skin. In the microscopic examination, pyriform-shaped parasites were seen to be attached to the epithelial cells of the skin with hypertrophied proboscis. In the epidermis, mild hyperplasia of the malphigian cells and depletion of the goblet cells were observed where Ichthyobodo spp. was dense (Figure 1b, c) and significant spongiosis, vacuolar degeneration, and hyperplasia of malpighian cells were seen where Ichthyobodo spp. were less dense or absent. There was also significant hyperplasia of the goblet cells (Figure 1d, e). In addition, epidermal cells were seen to have lost their interdigitating cell membranes, and the outer surface layers of the epidermis occasionally seemed to slough off (Figure 1f). Although the gill filaments were lightly infected, there was no apparent pathological change seen.

\section{DISCUSSION}

Although there have been reports on the occurrence of Ichthyobodo spp. in fish hosts from Turkey (7-10), in the present study, Ichthyobodo spp. is reported for the first time in meagre, A. regius, in Turkey.

The skin of infected meagres showed extensive epidermal hyperplasia, vacuolation, and spongiosis within this study. Symptoms resembled those seen in farmed salmonids infected with I. necator (11-13) and in Japanese flounder with Ichthyobodo spp. $(14,15)$. In previous studies, epidermal hyperplasia, vacuolation, and spongiosis were seen to occur in densely infected areas, but in contrast with these studies, these findings were seen in less densely infected areas in this study. This condition was attributed to the unattachment of the parasites to the epithelial cells due to the degeneration of the upper level epidermis cells. Previous studies reveal optimal or high mortality rates in densely infected farms, but in the present study, the insignificant mortality rate was thought to be correlated with the early

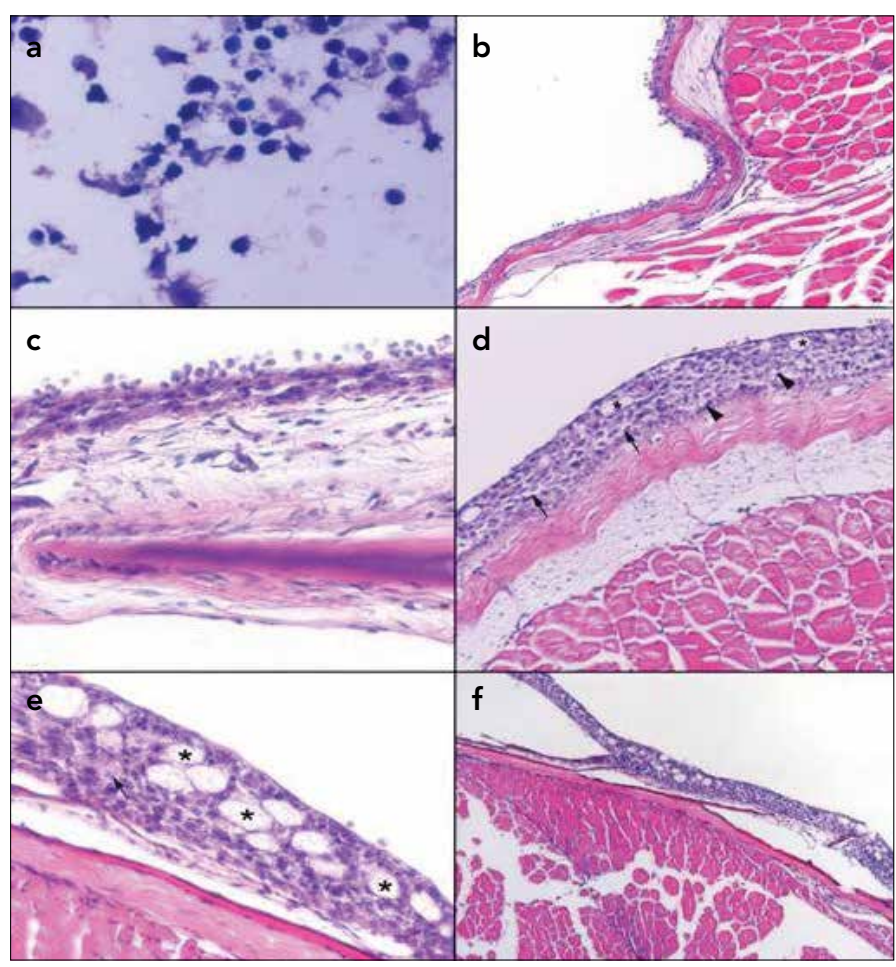

Figure 1. a. f. Wet mounts of the free-swimming stage of Ichthyobodo spp. (Giemsa, X1000). b, c. Skin surface of a meagre excessively infected with Ichthyobodo spp. of epidermis and absence of goblet cells (HE, X200; X400). d,e. Epidermis of a meagre less densely infected with Ichthyobodo spp. showing of the hyperplasia of malpighian cell and goblet cells (asterisk), severe vacuolation (arrowheads) and spongiosis (arrows) (HE, X200; X400). f. Sloughing of the epidermis of an infected meagre (HE, X100). 
diagnosis and treatment protocol. The cytoplasmic degeneration occurring around the parasite's cytostome suggested that the parasite may feed on the cytoplasm by releasing digestive enzymes or toxic substances from the cytostome tube, as suggested in I. necator (12). The main cause of fish deaths may be attributable to breakdown of the osmoregulatory system due to severe epidermal destruction, followed by the starvation of fish due to decreased appetite.

Although Ichthyobodo spp. was reported in both the gills and skin of fish (6), the parasites in the present investigation showed a distribution in the meagre juveniles, where they were abundant on the skin surface and fins, but rare on the gills. In the present study, Ichthyobodo spp. on meagres was found to occur in large numbers over the whole body surface, indicating the possibility of direct skin infections.

\section{CONCLUSION}

With this study, Ichthyobodo spp. infection in meagre, a very popular alternative species in the last few years, was determined parasitologically and pathologically. This study demonstrates that the marine Ichthyobodo spp. is an important parasitic pathogen of meagre, and is responsible for growth retardation and mortalities in fish culture facilities. It can cause large economic losses in marine aquaculture. An effective method for controlling Ichthyobodo infections is formalin treatment, but further investigations should be directed to prevent outbreaks of ichthyobodiasis.

Etik Komite Onayı: Bu çalışma için etik komite onayına gerek yoktur.

Hasta Onamı: Bu çalışma için hasta onamına gerek yoktur.

Hakem Değerlendirmesi: Dış Bağımsız.

Yazar Katkıları: Fikir - B.Y., G.Z.P., B.I.D., S.M. ; Tasarım - B.Y., G.Z.P.; Denetleme - B.I.D., S.M.; Kaynaklar - B.Y., B.I.D.; Malzemeler - ; Veri Toplanması ve/veya işlemesi - B.Y., B.I.D.; Analiz ve/veya Yorum B.Y., G.Z.P.; Literatür taraması - B.Y., G.Z.P.; Yazıyı Yazan - B.Y.; Eleştirel inceleme - B.I.D

Çıkar Çatışması: Yazarlar çıkar çatışması bildirmemişlerdir.

Finansal Destek: Finansal destek yoktur.

Ethics Committee Approval: Ethics Committee Approval was not needed for this study.

Informed Consent: Not required in this study.

Peer-review: Externally peer-reviewed.

Author contributions: Consept - B.Y., G.Z.P., B.I.D., S.M.; Design - B.Y., G.Z.P.; Supervision - B.I.D., S.M.; Funding - B.Y., B.I.D; Materials; Data Collection and/or Processing - B.Y., B.I.D.; Analysis and/or Interpretation B.Y., G.Z.P; Literature Review - B.Y., G.Z.P.; Writer - B.Y.; Critical Review - B.I.D.
Conflict of Interest: The authors have no conflict of interest.

Financial Disclosure: The study has not been founded.

\section{REFERENCES}

1. Monfort MC. Present market situation and prospects of meagre (Argyrosomus regius), as an emerging species in Mediterranean aquaculture. In, Studies and Reviews no. 89. General Fisheries Commission for the Mediterranean, Food and Agriculture Organization of the United Nations (FAO). pp. 46, 2010.

2. FAO. Fisheries and aquaculture department. Available at: http:// www.fao.org/fishery, 2013, (accessed on 01 September 2014).

3. Isaksen TE, Karlsbakk E, Repstad O, Nylund A. Molecular tools for the detection and identification of Ichthyobodo spp. (Kinetoplastida), important fish parasites. Parasitol Int 2012; 61: 675-83. [CrossRef]

4. Rodger HD, Murphy K, Mitchell SO, Henry L. Gill disease in marine farmed Atlantic salmon at four farms in Ireland. Vet Rec 2011; 168: 668. [CrossRef]

5. Todal JA, Karlsbakk E, Isaksen TE, Plarre H, Urawa S, Mouton A, et al. Ichthyobodo necator (Kinetoplastida) - a complex of sibling species. Dis Aquat Organ 2004; 58: 9-16. [CrossRef]

6. Lom J, Dykova L. Protozoan Parasites of Fishes. In, Lom J, Dykova L (Eds): Developments in Aquaculture and Fisheries Science. Vol. 26, Elsevier, Amsterdam, 1992.

7. Ogut $H$, Akyol A. Prevalence and intensity of ectoparasites in rainbow trout (Oncorhynchus mykiss) from larvae stage to market size in Turkey. Isr J Aquacult- Bamid 2007; 59: 23-31.

8. Balta F, Kayis S, Altinok I. External protozoan parasites in three trout species in the Eastern Black Sea region of the Turkey: intensity, seasonality, and their treatments. Bull Eur Assoc Fish Pathol 2008; 28: 157-62.

9. Koyuncu, E. 2009. Parasites of ornamental fish in Turkey. Bull Eur Assoc Fish Pathol 29: 25-7.

10. Tokşen, E. First detection of Ichthyobodo spp. infection and its treatment in a sea bream (Sparus aurata L.) farm in Izmir. Türkiye Parazitoloji Dergisi 2000; 24: 321-5.

11. Robertson DA. Host-parasite interactions between Ichtyobodo necator (Henneguy, 1883) and farmed salmonids. J Fish Dis 1979; 2: 481-91. [CrossRef]

12. Roubal FR, Bullock AM, Robertson DA, Roberts RJ. Ultrastructural aspects of infestation by Ichthyobodo necator (Henneguy, 1883) on the skin and gills of the salmonids Salmo salar L. and Salmo gairdneri Richardson. J Fish Dis 1987; 10: 181-92. [CrossRef]

13. Isaksen TE, Karlsbakk E, Sundnes GA, Nylund A. Patterns of Ichthyobodo necator sensu stricto infections on hatchery reared salmon (Salmo salar L.) in Norway. Dis Aquat Organ 2010; 88: 20714. [CrossRef]

14. Urawa S, Ueki N, Nakai T, Yamasaki H. High mortality of cultured juvenile Japanese flounder, Paralichthys olivaceus (Temminek \& Sehlegel), eaused by the parasitic flagellate Ichthyobodo sp. J Fish Dis 1991; 14: 489-94. [CrossRef]

15. Urawa S, Ueki N, Karlsbakk E. A review of Ichthyobodo infection in marine fishes. Fish Pathol 1998; 33: 311-20. [CrossRef] 